\title{
Pengaruh Kompetensi SDM, Moralitas dan Sistem Pengendalian Internal Terhadap Pencegahan Fraud Dalam Pengelolaan Keuangan Desa
}

\author{
Putu Santi Putri Laksmi ${ }^{1}$ \\ I Ketut Sujana ${ }^{2}$ \\ ${ }^{1,2}$ Fakultas Ekonomi dan Bisnis Universitas Udayana (Unud), Bali, Indonesia \\ e-mail: santilaksmi2@gmail.com
}

\begin{abstract}
ABSTRAK
Penelitian ini dilakukan pada 27 Desa Dinas di Kota Denpasar dengan menggunakan metode total atau sensus. Responden yang digunakan sebanyak 97 orang yang terdiri dari Kepala Desa, Sekertaris Desa, Bendahara dan Badan Permusyawaratan Desa (BPD). Teknik analisis data yang digunakan adalah analisis regresi linier berganda.Hasil penelitian ini menunjukkan bahwa kompetensi sumber daya manusia berpengaruh positif terhadap pencegahan fraud dalam pengelolaan keuangan desa. Moralitas berpengaruh positif terhadap pencegahan fraud dalam pengelolaan keuangan desa. Sistem pengendalian internal berpengaruh positif terhadap pencegahan fraud dalam pengelolaan keuangan desa. Hal ini berarti, dengan adanya kompetensi sumber daya manusia, moralitas yang baik dan sistem pengendalian internal yang kuat, maka dapat mencegah terjadinya tindakan kecurangan dalam pengelolaan keuangan desa.

Kata kunci :Kompetensi sumber daya manusia, moralitas, sistem pengendalian, internal, fraud
\end{abstract}

\begin{abstract}
This research was conducted at 27 Service Villages in Denpasar City using a total method or census. The respondents used were 97 people consisting of the Village Head, Village Secretary, Treasurer and Village Consultative Body (BPD). The data analysis technique used is multiple linear regression analysis. The results of this study indicate that the competence of human resources has a positive effect on prevention of fraud in village financial management. Morality has a positive effect on prevention of fraud in managing village finances. The internal control system has a positive effect on preventing fraud in managing village finances. This means, with the competency of human resources, good morality and a strong internal control system, it can prevent fraud in managing village finances.
\end{abstract}

Keywords: Human resource competency, morality, control system, internal, fraud

\section{PENDAHULUAN}

Saat ini arah dan strategi dalam kebijakan pembangunan desa dan perdesaan Pemerintah tidak dapat dipisahkan dari visi misi Presiden untuk membangun Indonesia dari pinggiran dengan memperkuat daerah dan desa dalam kerangka Negara Kesatuan Republik Indonesia (NKRI). Pemerintah Indonesia melalui 
program Nawacita Presiden Joko Widodo memiliki komitmen untuk membangun Indonesia dengan meningkatkan pembangunan di desa. Dalam mendukung pelaksanaan tugas dan fungsi desa dalam penyelenggaraan pemerintahan dan pembangunan desa dalam segala aspeknya, Undang-Undang Republik Indonesia Nomor 6 Tahun 2014 tentang Desa memberikan mandat kepada Pemerintah untuk mengalokasikan dana desa.

Undang-Undang Republik Indonesia Nomor 6 Tahun 2014 Pasal 72 tentang Desa menjelaskan bahwa alokasi dana desa merupakan dana perimbangan yang diterima Kabupaten atau Kota paling sedikit 10\% (sepuluh perseratus) dalam Anggaran Pendapatan dan Belanja Daerah (APBD) setelah dikurangi dana aloksi khusus yang digunakan untuk mendanai penyelenggaraan pemerintahan desa, pelaksanaan pembangunan desa, pembinaan dan pemberdayaan masyarakat. Alokasi dana desa hakekatnya memiliki tujuan yaitu untuk menanggulangi kemiskinan dan mengurangi kesenjangan, meningkatkan perencanaan dan penganggaran pembangunan di tingkat desa, meningkatkan pelayanan dan pemberdayaan masyarakat desa dalam rangka mengembangkan kegiatan sosial dan ekonomi masyarakat serta meningkatkan pendapatan desa dan masyarakat desa melalui Badan Usaha Milik Desa (BUMDesa) (Peraturan Menteri Dalam Negeri Nomor 37 Tahun 2007 tentang Pedoman Pengelolaan Keuangan Desa).

Pembagian alokasi dana desa yang diterima oleh masing-masing desa di setiap wilayah berbeda-beda. Hal tersebut dikarenakan, pemberian alokasi dana desa didasarkan pada jumlah penduduk, angka kemiskinan, luas wilayah desa dan tingkat kesulitan desa. Pembagian dan tata cara pemberian alokasi dana desa 
dilakukan melalui keputusan yang dibuat oleh Pemerintah Daerah di masingmasing wilayah yaitu berdasarkan pada peraturan Bupati atau Walikota.

Alokasi dana desa merupakan bagian dari pengelolaan keuangan desa yang diuraikan lebih rinci melalui APBDes. Pengelolaan keuangan desa dilaksanakan oleh Pemerintah Desa. Pemerintah Desa merupakan orang yang memiliki wewenang dan tanggungjawab dalam melaksanakan penyelenggaraan di Pemerintahan Desa, yaitu Kepala Desa yang dibantu oleh Sekertaris Desa, Bendahara dan Kepala Seksi. Pengelolaan keuangan desa harus berdasarkan pada prinsip transparansi, akuntabel, partisipatif serta dilakukan dengan tertib dan disiplin anggaran yang telah tertuang dalam Peraturan Menteri Dalam Negeri Nomor 113 Tahun 2014 tentang Pengelolaan Keuangan Desa. Dalam pengelolaan keuangan desa terdapat hubungan keagenan yang terjadi antara Pemerintah Desa selaku agent dan Pemerintah Pusat maupun Pemerintah Daerah sebagai principal.

Pemberian alokasi dana desa yang besar memiliki konsekuensi untuk terjadinya kecurangan yang dilakukan oleh pihak-pihak tertentu, khususnya pihak pihak yang telah dipercaya oleh masyarakat. Kecurangan (fraud) merupakan tindakan yang dilakukan seseorang atau berkelompok secara ilegal baik disengaja maupun tidak disengaja untuk memperoleh keuntungan dengan cara mendapatkan uang, aset dan lain sebagainya sehingga dapat merugikan orang lain atau pihak tertentu (Aini et al., 2017). Berdasarkan konsep fraud triangel yang dibuat oleh Cressy terdapat tiga hal yang mendorong terjadinya kecurangan yaitu tekanan, kesempatan dan rasionalisasi (Tuanakotta, 2012:205). GONE Theory menjelaskan terdapat empat faktor penyebab kecurangan berdasarkan pandangan dari sisi 
perilaku manusia yaitu keserakahan, kesempatan, kebutuhan dan pengungkapan. Keserakahan berkaitan dengan terdapatnya perilaku serakah yang berada di dalam diri individu, kesempatan berkaitan dengan keadaan organisasi atau instansi atau masyarakat yang memberikan peluang bagi individu untuk melakukan kecurangan, kebutuhan berkaitan dengan faktor-faktor yang dimiliki seseorang untuk menunjang hidupnya dan pengungkapan berkaitan dengan tindakan yang akan dihadapi oleh pelaku yang melakukan tindakan kecurangan (Bologne et al., 1987 dalam Manasooh 2016).

Fenomena kasus pengelolaan keuangan desa sudah banyak terjadi di Indonesia. Hasil pemantauan yang dilakukan oleh Indonesia Corruption Watch (ICW) menyebutkan pada tahun 2015 sampai 2017 kasus tindakan korupsi di desa semakin meningkat. Terdapat 127 kasus penyalahgunaan anggaran desa yang terjadi. Penyalahgunaan anggaran desa rata-rata dilakukan oleh Kepala Desa (Indonesia Corruption Watch, 2018). Berdasarkan hasil kajian yang dilakukan oleh Komisi Pemberantas Korupsi (KPK), KPK mengidentifikasi adanya empat aspek yang dapat memicu terjadinya korupsi dalam pengelolaan keuangan desa yaitu pada aspek regulasi dan kelembagaan, aspek tata laksana, aspek pengawasan dan aspek sumber daya manusia (Liputan 6, 2017).

Di tahun 2018 terdapat dugaan penyelewengan dana desa yang terjadi di Kota Denpasar. Berdasarkan hasil temuan dari Unit Satreskim Tipikor Polresta Denpasar, terdapat dugaan penyalahgunaan keuangan desa di Desa Pemecutan Kaja, Kecamatan Denpasar Utara yang dilakukan oleh Kepala Desa sejak bulan Januari 2017 hingga Januari 2018. Kerugian keuangan desa dalam kasus tersebut 
mencapai Rp 123 juta (Berita Bali, 2018). Berdasarkan laporan hasil pengawasan semester II yang dilakukan oleh Badan Pengawasan Keuangan dan Pembangunan (BPKP) Provinsi Bali, terdapat beberapa masalah pada pengelolaan dana desa di Kota Denpasar. Adapun permasalahan yang terjadi, yaitu pada penatausahaan pengelolaan keuangan desa masih terdapat kesalahan dalam implementasi aplikasi siskeudes, terdapat kesalahan penganggaran dalam APBDes, BUMDesa belum menetapkan anggaran dasar dan anggaran rumah tangga serta belum dilakukannya pencatatan aset atas pekerjaan yang sudah selesai (BPKP, 2018).

Berdasarkan fenomena di atas, selain diperlukannya partisipasi masyarakat dalam mengawasi dan mengevaluasi penggunaan keuangan desa, tindakan pencegahan juga dibutuhkan untuk meminimalisir terjadinya tindakan penyelewengan. Pencegahan kecurangan (fraud) merupakan upaya atau tindakan yang dilakukan untuk menekan atau mencegah terjadinya faktor penyebab kecurangan. Pencegahan kecurangan dalam pengelolaan keuangan desa dapat dilakukan dengan adanya kompetensi dari sumber daya manusia, menanamkan moralitas kepada setiap individu dan terdapat sistem pengendalian internal.

Putri et al., (2017) mengatakan bahwa Pemerintah Desa dalam hal melakukan pengelolaan keuangan desa dituntut untuk melaksanakan tugas-tugas secara akuntabel dan transparan agar tidak terjadi tindakan penyelewengan dana. Oleh karena itu, kompetensi sumber daya manusia yang berkualitas sangat dibutuhkan untuk melaksanakan tugas dan kewajiban dalam pengelolaan keuangan desa. Kompetensi sumber daya manusia merupakan kemampuan yang dimiliki seseorang atau individu dalam menghadapi situasi atau keadaan dalam 
melaksanakan tanggungjawab pekerjaanya. Berdasarkan Undang-Undang Nomor 13 Tahun 2013 tentang Ketenagakerjaan, faktor kompetensi seseorang berkaitan dengan kemampuan individu yang mencakup aspek pengetahuan, keterampilan dan sikap kerja. Wardani dan Ika (2017) menjelaskan bahwa dalam pengelolaan keuangan daerah yang baik, perangkat desa harus memiliki sumber daya manusia yang berkualitas, didukung dengan latar belakang pendidikan dan pelatihan serta mempunyai pengalaman di bidang keuangan. Kurangnya kompetensi dalam memahami dan menerapkan logika akuntansi akan memiliki pengaruh terhadap kekeliruan laporan keuangan yang dibuat dan ketidaksesuaian laporan dengan standar yang telah ditetapkan oleh Pemerintah, sehingga informasi yang diterima oleh pengguna akan tidak tepat serta akan mempengaruhi keputusan yang akan diambil selanjutnya (Ferina et al., 2016).

Penelitian yang dilakukan oleh Atmadja dan Komang (2017) menyatakan bahwa kompetensi aparatur berpengaruh terhadap pencegahan fraud dalam pengelolaan keuangan desa. Pernyataan tersebut didukung oleh penelitian yang dilakukan oleh Mahayani (2017) yang menyatakan bahwa kompetensi sumber daya manusia berpengaruh positif pada akuntanbilitas pengelolaan dana desa. Namun hasil penelitian tersebut tidak sejalan dengan penelitian yang dilakukan oleh Indriani et al., (2016) yang menyatakan bahwa kompetensi tidak berpengaruh terhadap kecenderungan terjadinya perilaku fraud.

Moralitas dapat mempengaruhi etika atau perbuatan yang dilakukan oleh seseorang. Moralitas individu akan berhubungan pada kecenderungan seseorang untuk melakukan kecurangan akuntansi (Dennyningrat dan I.D.G Dharma, 2018). 
Untuk mencegah kecurangan (fraud), maka upaya yang dapat dilakukan dengan mengedepankan dan menanamkan pemikiran tentang moralitas (Novikasari, 2017). Moralitas atau moral merupakan baik buruknya sikap atau perilaku yang dimiliki oleh seseorang (Junia, 2016). Seseorang yang memiliki penalaran moral yang rendah akan memiliki perilaku yang berbeda dengan seseorang yang memiliki moral yang tinggi dalam menghadapi dilema etika (Liyanarachchi dan Chris, 2009). Menurut Rahimah et al., (2018) individu yang mempunyai tingkat moral yang tinggi akan dapat mencegah terjadinya kecurangan karena individu yang mempunyai moral tinggi akan menaati aturan sesuai dengan prinsip-prinsip etika universal, begitupun sebaliknya, individu yang memiliki moral yang rendah cenderung membuat keputusan berdasarkan hal yang diinginkan oleh dirinya sendiri dan tidak menaati peraturan dan kewajiban yang seharunya dipenuhi. Manossoh (2016) menjelaskan bahwa pejabat yang memiliki perilaku yang baik akan membuat pengelolaan keuangan berjalan dengan baik, dan begitu pun sebaliknya.

Adapun penelitian mengenai pengaruh moralitas terhadap pencegahan fraud yaitu penelitian yang dilakukan oleh Wardana et al., (2017) menyatakan bahwa secara parsial moralitas aparat berpengaruh terhadap pencegahan fraud. Pernyataan tersebut didukung oleh penelitian yang dilakukan oleh Setiawan (2018) yang menyatakan bahwa moralitas individu berpengaruh terhadap kecurangan akuntansi. Namun hasil penelitian tersebut tidak sejalan dengan penelitian yang dilakukan oleh Dewi et al., (2017) yang menyatakan bahwa moralitas tidak berpengaruh signifikan terhadap pencegahan fraud. 
Tindakan kecurangan (fraud) dalam pengelolaan keuangan desa dapat diminimalisir dan dicegah dengan memperhatikan sistem pengendalian internalnya. Sistem pengendalian internal merupakan proses yang dijalankan untuk memberikan keyakinan terhadap pencapaian keandalan laporan keuangan dan kepatuhan terhadap hukum (Adi et al., 2016). Committee of Sponsoring Organizations (2013:4) menjelaskan terdapat lima indikator yang terdapat dalam sistem pengendalian internal yaitu lingkungan pengendalian, penilaian risiko, kegiatan pengendalian, informasi dan komunikasi serta pemantauan pengendalian internal. Sistem pengendalian internal yang baik mampu mencegah terjadinya fraud dalam pengelolaan keuangan desa, terlebih bahwa keuangan desa diawasi oleh Pemerintah Pusat, Provinsi, Kabupaten atau Kota dan lembaga keuangan independen (Atmadja dan Komang, 2017). Semakin kuat sistem pengendalian internal yang terdapat pada Pemerintahan Desa maka tindakan kecurangan dan kesalahan yang mungkin terjadi pada pengelolaan keuangan desa dapat diminimalisir dan dicegah dan jika pengendalian internalnya lemah maka tindakan kecurangan yang akan terjadi semakin besar.

Fraud merupakan kecurangan yang memiliki arti terhadap sesuatu yang menyimpang dan perbuatan melanggar hukum yang dilakukan dengan sengaja untuk menipu atau memberikan suatu gambaran atau tafsiran yang keliru kepada pihak-pihak tertentu, baik dari dalam maupun luar organisasi (Karyano, 2013:4). Tindakan fraud yang dilakukan dapat menimbulkan banyak kerugian baik secara material maupun non material seperti, hancurnya reputasi organisasi, kerugian 
keuangan negara, rusaknya moralitas karyawan serta dampak-dampak negatif lainnya (Indriani et al., 2016).

Terdapat dua jenis kecurangan akuntansi menurut Ikatan Akuntan Indonesia (2001), yang pertama adalah salah saji yang timbul dari kecurangan dalam pelaporan keuangan yaitu salah saji atau penghilangan secara sengaja jumlah atau pengungkapan dalam laporan keuangan yang bertujuan untuk mengelabuhi pemakai laporan keuangan dan yang kedua adalah salah saji yang timbul dari perlakuan tidak semestinya terhadap aktiva (seringkali disebut dengan penyalahgunaan atau penggelapan).

Penelitian yang dilakukan oleh Nisak et al., (2013) menyatakan bahwa sistem pengendalian internal berpengaruh terhadap pencegahan fraud. Pernyataan tersebut didukung oleh penelitian yang dilakukan Josephn et al., (2015) yang menyatakan terdapat hubungan signifikan dan positif antara sistem pengendalian internal terhadap pencegahan dan pendektesian fraud. Namun, hasil penelitian tersebut tidak sejalan dengan penelitian yang dilakukan Usman et al., (2015) yang menyatakan bahwa sistem pengendalian internal tidak berpengaruh signifikan terhadap pencegahan kecurangan.

Sugiarti dan Ivan (2017) menjelaskan bahwa kompetensi sumber daya manusia mencakup kapasitasnya yaitu kemampuan seorang individu, suatu organisasi (kelembagaan) atau suatu sistem untuk melaksanakan fungsi-fungsi atau kewenangannya untuk mencapai tujuannya secara efektif dan efesien. Kapasitas harus dilihat sebagai kemampuan untuk mencapai kinerja, untuk menghasilkan output dan outcome. Di dalam pengelolaan keuangan desa, 
pemerintah desa harus memiliki kompentensi sumber daya manusia yang berkualitas yang didukung dengan latar belakang pendidikan, pengalaman, mengikuti pelatihan, mengerti tentang akuntansi dan keuangan desa dan memahami peraturan serta prosedur mengenai pengelolaan keuangan desa berserta tujuan dana tersebut diberikan oleh Pemerintah. Hal tersebut di perlukan agar tidak terjadi kekeliruan dalam pengelolaan keuangan desa dan ketidaksesuaian laporan yang dibuat berdasarkan standar pengelolaan keuangan yang sudah di tetapkan oleh Pemerintah.

Penelitian yang dilakukan oleh Huslina (2015) menyatakan bahwa kompetensi aparatur berpengaruh positif terhadap efektivitas sistem pencegahan fraud. Penelitian tersebut didukung oleh penelitian yang dilakukan oleh Widiyarta et al., (2017) yang menyatakan bahwa kompetensi pemerintah desa berpengaruh positif dan signifikan terhadap pencegahan fraud dalam pengelolaan dana desa. Berdasarkan ulasan diatas, maka hipotesis dalam penelitian ini adalah sebagai berikut.

$\mathrm{H}_{1}$ : Kompetensi sumber daya manusia berpengaruh positif terhadap pencegahan fraud dalam pengelolaan keuangan desa.

Moralitas atau yang biasanya disebut dengan moral merupakan ajaran tentang baik buruknya perbuatan dan sikap yang dimiliki oleh seseorang atau individu sedangkan bermoral merupakan pertimbangan akan baik buruknya akhlak seseorang (Junia, 2016). Moralitas sangat diperlukan untuk mencegah tindakan fraud atau kecurangan yang dilakukan khususnya pada pengelolaan keuangan desa, hal tersebut dikarenakan apabila seseorang memiliki moralitas yang baik maka penggunaan dan pengelolaan dana desa akan berjalan sesuai 
dengan kebutuhan yang diprioritaskan. Hal ini sejalan dengan penelitian yang dilakukan oleh Wardana et al., (2017) yang menyatakan bahwa secara parsial moralitas aparat berpengaruh terhadap pencegahan fraud dan Rahimah et al., (2018) yang membuktikan bahwa moralitas berpengaruh terhadap pencegahan fraud dalam alokasi dana desa. Berdasarkan ulasan diatas, maka hipotesis dalam penelitian ini adalah sebagai berikut.

$\mathrm{H}_{2}$ : Moralitas berpengaruh positif terhadap pencegahan fraud dalam pengelolaan keuangan desa.

Sistem pengendalian internal merupakan suatu cara untuk mengawasi, mengarahkan serta mengukur sumber daya suatu lembaga atau organisasi serta memiliki peran yang penting di dalam pencegahan dan pendeteksian adanya tindakan fraud atau kecurangan. Pengendalian internal harus memiliki kebijakan dan prosedur yang jelas yang bertujuan agar dapat menjamin dan menyediakan laporan informasi keuangan yang sesuai dengan prosedur yang telah ditetapkan (Wardani dan Ika, 2017). Dengan adanya sistem pengendalian internal maka proses pengelolaan keuangan desa dapat diarahkan, diawasi dan dapat dideteksi apabila terdapat penyelewengan sehingga laporan tersebut dapat dipertanggungjawabkan.

Hal tersebut selaras dengan penelitian Soleman (2013) yang menyatakan pengendalian internal berpengaruh positif terhadap pencegahan fraud dan penelitian yang dilakukan oleh Atmadja dan Komang (2017) yang menyatakan bahwa sistem pengendalian internal berpengaruh terhadap pencegahan fraud dalam pengelolaan keuangan desa. Berdasarkan ulasan diatas, maka hipotesis dalam penelitian ini adalah sebagai berikut. 
$\mathrm{H}_{3}$ : Sistem pengendalian internal berpengaruh positif terhadap pencegahan fraud dalam pengelolaan keuangan desa.

\section{METODE PENELITIAN}

Lokasi penelitian merupakan lokasi atau wilayah yang dipilih oleh peneliti untuk melakukan penelitian. Penelitian ini dilakukan di Kota Denpasar. Adapun alasan peneliti memilih Kota Denpasar, yaitu berdasarkan hasil temuan dari Unit Satreskim Tipikor Polresta Denpasar, terdapat dugaan penyalahgunaan keuangan desa di Desa Pemecutan Kaja, Kecamatan Denpasar Utara yang dilakukan oleh Kepala Desa sejak bulan Januari 2017 hingga Januari 2018. Kerugian keuangan desa dalam kasus tersebut mencapai Rp 123 juta (Berita Bali, 2018).

Berdasarkan laporan hasil pengawasan semester II yang dilakukan oleh Badan Pengawasan Keuangan dan Pembangunan (BPKP) Provinsi Bali, terdapat beberapa masalah pada pengelolaan dana desa di Kota Denpasar. Adapun permasalahan yang terjadi, yaitu pada penatausahaan pengelolaan keuangan desa masih terdapat kesalahan dalam implementasi aplikasi siskeudes, terdapat kesalahan penganggaran dalam APBDes, BUMDesa belum menetapkan anggaran dasar dan anggaran rumah tangga serta belum dilakukannya pencatatan aset atas pekerjaan yang sudah selesai (BPKP, 2018).

Populasi dari penelitian ini adalah Pemerintah Desa yang terlibat dalam pengelolaan keuangan desa yang dimulai dari tahap perencanaan, pelaksanaan, penatausahaan, pelaporan dan pertanggungjawaban, yaitu terdiri dari Kepala 
Desa, Sekertaris Desa, Bendahara Desa dan Badan Permusyawaratan Desa (BPD) di 27 (dua puluh tujuh) Desa Dinas di Kota Denpasar.

Teknik non probability sampling yang digunakan adalah sampling total atau sensus yaitu teknik pengembalian sampel di mana seluruh anggota populasi dijadikan sampel semua (Sugiyono, 2018:126). Pada penelitian ini, sampel yang digunakan adalah 27 Desa Dinas di Kota Denpasar. Responden dalam penelitian ini sebanyak 108 orang.

Teknik analisis data yang digunakan dalam penelitian ini adalah analisis linier berganda. Analisis data didasarkan pada kuesioner yang dinilai berdasarkan skala linkert 4 poin. Tahapan analisis data dalam penelitian ini adalah statistik deskriptif, uji asumsi klasik yang terdiri dari uji normalitas, uji multikolinieritas, dan uji heteroskedastisitas serta uji analisis linier berganda, koefisien determinasi $\left(\mathrm{R}^{2}\right)$, uji F ( uji kelayakan model) dan uji t (uji hipotesis).

Persamaan regresi linier berganda dapat dirumuskan sebagai berikut.

$$
\mathrm{Y}=\alpha+\beta_{1} \mathrm{X}_{1}+\beta_{2} \mathrm{X}_{2}+\beta_{3} \mathrm{X}_{3}+\mathrm{e}
$$

Keterangan:

$\mathrm{Y} \quad=$ Pencegahan fraud dalam pengelolaan keuangan desa

$\alpha \quad=$ Konstanta

$\beta_{1}, \beta_{2}, \beta_{3}, \quad=$ Koefisien Regresi

$\mathrm{X}_{1} \quad=$ Kompetensi Pemerintah Desa

$\mathrm{X}_{2} \quad=$ Moralitas

$\mathrm{X}_{3} \quad=$ Sistem Pengendalian Internal

$\mathrm{e} \quad=$ Standar eror

\section{HASIL DAN PEMBAHASAN}

Analisis data deskriptif dilakukan untuk memberikan gambaran atau deskripsi mengenai variabel yang diteliti dimana terdiri dari kompetensi sumber daya 
manusia $\left(\mathrm{X}_{1}\right)$, moralitas $\left(\mathrm{X}_{2}\right)$, sistem pengendalian internal $\left(\mathrm{X}_{3}\right)$ dan pencegahan fraud dalam pengelolaan keuangan desa (Y). Statistik deskriptif penelitian diolah dengan menggunakan SPSS versi 21. Hasil dari analisis data statistik deskriptif dapat dilihat pada Tabel 1 berikut.

Tabel 1.

Hasil Statistik Deskriptif

\begin{tabular}{lccccc}
\hline & N & Minimum & Maksimum & Rata-rata & Standar Deviasi \\
\hline$X_{1}$ & 97 & 2,60 & 4 & 3,31 & 0,350 \\
$X_{2}$ & 97 & 2,40 & 4 & 3,19 & 0,376 \\
$X_{3}$ & 97 & 2,36 & 4 & 3,29 & 0,388 \\
$Y$ & 97 & 2 & 4 & 3,12 & 0,364
\end{tabular}

Valid N (listwise)

Sumber: Data diolah, 2018

Nilai minimum pada variabel kompetensi sumber daya manusia sebesar 2,60 berarti nilai terendah dari variabel tersebut sebesar 2,60 dan nilai maksimum sebesar 4 artinya nilai tertinggi sebesar 4 . Nilai rata-rata pada variabel kompetensi sumber daya manusia sebesar 3,31. Nilai rata-rata tersebut mencerminkan kecenderungan responden menjawab setuju pada 10 item pernyataan mengenai kompetensi sumber daya manusia pada kuesioner. Nilai standar deviasi sebesar 0,350 lebih kecil dari nilai rata-ratanya, artinya penyimpangan data pada variabel kompetensi sumber daya manusia sangat kecil.

Nilai minimum pada variabel moralitas sebesar 2,40 berarti nilai terendah dari variabel tersebut sebesar 2,40 dan nilai maksimum sebesar 4 artinya nilai tertinggi sebesar 4. Nilai rata-rata pada variabel moralitas sebesar 3,19. Nilai ratarata sebesar 3,19 memiliki arti bahwa, pada pernyataan nomor 1 sampai dengan nomor 3, responden cenderung menjawab tidak setuju pada kasus dilema etika, dimana pernyataan nomor 1 sampai nomor 3 untuk jawaban tidak setuju mendapatkan nilai 3. Dan pernyataan nomor 4 dan 5 , responden menjawab setuju 
pada pernyataan tersebut, dimana untuk jawaban setuju mendapatkan nilai 3. Nilai standar deviasi sebesar 0,376 lebih kecil dari nilai rata-ratanya, artinya penyimpangan data pada variabel moralitas sangat kecil.

Nilai minimum pada variabel sistem pengendalian internal sebesar 2,36 berarti nilai terendah dari variabel tersebut sebesar 2,36 dan nilai maksimum sebesar 4 artinya nilai tertinggi sebesar 4 . Nilai rata-rata pada variabel sistem pengandalian internal sebesar 3,29. Nilai rata-rata tersebut mencerminkan kecenderungan responden menjawab setuju pada 11 item pernyataan mengenai sistem pengendalian internal. Nilai standar deviasi sebesar 0,388 lebih kecil dari nilai rata-ratanya, artinya penyimpangan data pada variabel sistem pengedalian internal sangat kecil.

Nilai minimum pada variabel pencegahan fraud dalam pengelolaan keuangan desa sebesar 2 berarti nilai terendah dari variabel tersebut sebesar 2 dan nilai maksimum sebesar 4 artinya nilai tertinggi sebesar 4 . Nilai rata-rata pada variabel pencegahan fraud dalam pengelolaan keuangan desa sebesar 3,19. Nilai rata-rata tersebut mencerminkan kecenderungan responden menjawab setuju pada 7 item pernyataan mengenai pencegahan fraud dalam pengelolaan keuangan desa pada kuesioner. Nilai standar deviasi sebesar 0,364 lebih kecil dari nilai rataratanya, artinya penyimpangan data pada variabel pencegahan fraud dalam pengelolaan keuangan desa sangat kecil.

Hasil rangkuman analisis regresi dapat dilihat pada Tabel 2. 
Tabel 2.

Hasil Uji Regresi Linier Berganda

\begin{tabular}{|c|c|c|c|c|c|}
\hline \multirow[t]{2}{*}{ Model } & \multicolumn{2}{|c|}{$\begin{array}{l}\text { Unstandardized } \\
\text { Coefficients }\end{array}$} & \multirow{2}{*}{$\begin{array}{l}\text { Standardized } \\
\text { Coefficients } \\
\text { Beta }\end{array}$} & \multirow[t]{2}{*}{$\mathbf{t}$} & \multirow[t]{2}{*}{ sig } \\
\hline & B & Std. Error & & & \\
\hline (Constant) & 3,005 & 2,355 & & 1,276 & 0,205 \\
\hline $\begin{array}{l}\text { Kompetensi Sumber } \\
\text { Dava Manusia }\left(X_{1}\right)\end{array}$ & 0,155 & 0,062 & 0,212 & 2,494 & 0,014 \\
\hline Moralitas $\left(\mathrm{X}_{2}\right)$ & 0,281 & 0,116 & 0,208 & 2,432 & 0,017 \\
\hline $\begin{array}{l}\text { Sistem Pengendalian } \\
\text { Internal }\left(\mathrm{X}_{3}\right)\end{array}$ & 0,256 & 0,054 & 0,428 & 4,771 & 0,000 \\
\hline $\mathrm{R}^{2}$ & $=0,436$ & & & & \\
\hline Adjusted $R$ Square & $=0,418$ & & & & \\
\hline F hitung & $=23,948$ & & & & \\
\hline Signifikansi & $=0,000$ & & & & \\
\hline
\end{tabular}

Berdasarkan Tabel 2, maka persamaan regresi dan arti dalam persamaan regresi yang digunakan dalam penelitian adalah sebagai berikut.

$$
\mathrm{Y}=3,005+0,155 \mathrm{X}_{1}+0,281 \mathrm{X}_{2}+0,256 \mathrm{X}_{3}
$$

Persamaan regresi (2) menunjukkan bahwa nilai konstantan ( $\alpha$ ) sebesar 3,005 yang memiliki arti bahwa variabel kompetensi sumber daya manusia $\left(\mathrm{X}_{1}\right)$, moralitas $\left(\mathrm{X}_{2}\right)$ dan sistem pengendalian internal $\left(\mathrm{X}_{3}\right)$ dinyatakan konstan pada angka 0, maka pencegahan fraud dalam pengelolaan keuangan desa akan meningkat sebesar konstantanya yaitu sebesar 3,005. Variabel kompetensi sumber daya manusia $\left(\mathrm{X}_{1}\right)$ memiliki koefisien beta bernilai positif sebesar 0,115 yang berarti, variabel kompetensi sumber daya manusia memiliki pengaruh positif terhadap pencegahan fraud dalam pengelolaan keuangan desa. Variabel moralitas $\left(\mathrm{X}_{2}\right)$ memiliki koefisien beta bernilai positif sebesar 0,281 yang berarti, variabel moralitas memiliki pengaruh positif terhadap pencegahan fraud dalam pengelolaan keuangan desa. Variabel sistem pengendalian internal $\left(\mathrm{X}_{3}\right)$ memiliki koefisien beta bernilai positif sebesar 0,256 yang berarti, variabel sistem 
pengendalian internal memiliki pengaruh positif terhadap pencegahan fraud dalam pengelolaan keuangan desa.

Hasil analisis regresi menunjukkan bahwa nilai Adjusted $R$ Square pada Tabel 2 sebesar 0,418. Hal ini berarti, pencegahan fraud dalam pengelolaan keuangan desa dapat dijelaskan oleh variabel kompetensi sumber daya manusia, moralitas dan sistem pengendalian internal sebesar 0,418 atau 41,8 persen sedangkan 0,582 atau 58,2 persen dijelaskan oleh faktor-faktor lain yang tidak diuji dalam penelitian ini.

Uji F atau uji kelayakan model digunakan untuk melihat apakah semua variabel bebas (independen) mempunyai pengaruh secara simultan terhadap variabel terikat (dependen) dengan tingkat signifikansi $\alpha=0,05$. Apabila tingkat signifikansi $\mathrm{F} \leq \alpha=0,05$ maka model ini dikatakan layak uji. Sebaliknya, jika tingkat signifikansi $\mathrm{F}>\alpha=0,05$ maka model persamaan regresi dapat dikatakan tidak layak uji. Berdasarkan hasil penelitian uji $\mathrm{F}$ pada Tabel 2 dapat dilihat bahwa nilai signifikansi sebesar $0,000 \leq 0,05$. Hal ini menunjukkan bahwa semua variabel bebas berpengaruh secara simultan terhadap variabel terikat dan model regresi ini layak digunakan.

Uji $\mathrm{t}$ digunakan untuk mengetahui pengaruh variabel bebas, yaitu kompetensi sumber daya manusia $\left(\mathrm{X}_{1}\right)$, moralitas $\left(\mathrm{X}_{2}\right)$ dan sistem pengendalian internal $\left(\mathrm{X}_{3}\right)$ secara parsial terhadap pencegahan fraud dalam pengelolaan keuangan desa (Y). Pengujian dapat dilakukan dengan membandingkan tingkat signifikansi masing-masing variabel bebas dengan $\alpha=0,05$. Jika nilai signifikansi $\mathrm{t}>0,05$ maka variabel bebas tidak mempunyai pengaruh terhadap variabel terikat, 
dan begitupun sebaliknya, jika nilai signifikansi $\mathrm{t} \leq 0,05$ maka variabel bebas mempunyai pengaruh terhadap variabel terikat (Ghozali, 2016:97).

Berdasarkan Tabel 2 dapat dilihat bahwa nilai signifikansi pada variabel $\mathrm{X}_{1}$ sebesar $0,014 \leq 0,05$, maka $\mathrm{H}_{0}$ ditolak dan $\mathrm{H}_{1}$ diterima. Hal ini berarti, kompetensi sumber daya manusia berpengaruh positif terhadap pencegahan fraud dalam pengelolaan keuangan desa.

Berdasarkan Tabel 2 dapat dilihat bahwa nilai signifikansi pada variabel $\mathrm{X}_{2}$ sebesar $0,017 \leq 0,05$, maka $\mathrm{H}_{0}$ ditolak dan $\mathrm{H}_{1}$ diterima. Hal ini berarti, moralitas berpengaruh positif terhadap pencegahan fraud dalam pengelolaan keuangan desa.

Berdasarkan Tabel 2 dapat dilihat bahwa nilai signifikansi pada variabel $\mathrm{X}_{3}$ sebesar $0,000 \leq 0,05$, maka $\mathrm{H}_{0}$ ditolak dan $\mathrm{H}_{1}$ diterima. Hal ini berarti, sistem pengendalian internal berpengaruh positif terhadap pencegahan fraud dalam pengelolaan keuangan desa.

Hipotesis satu $\left(\mathrm{H}_{1}\right)$ menyatakan bahwa kompetensi sumber daya manusia berpengaruh positif terhadap pencegahan fraud dalam pengelolaan keuangan desa. Hasil uji hipotesis yang telah dilakukan menunjukkan bahwa, kompetensi sumber daya manusia berpengaruh positif terhadap pencegahan fraud dalam pengelolaan keuangan desa. Hasil penelitian ini sesuai dengan agency theory (Jensen dan Meckling, 1976). Dalam agency theory menjelaskan bahwa terdapat hubungan antara principal dan agent, dimana principal menunjuk agent untuk melaksanakan suatu jasa dan memberikan wewenang kepada agent untuk mengambil keputusan. Dalam hal ini pemerintah Desa (agent) mendapatkan amanah dari Pemerintah Pusat maupun Daerah (principal) untuk menjalankan urusan Pemerintaha Desa 
khususnya dalam pengelolaan keuangan desa. Hal tersebut didukung oleh teori kepatuhan (compliance theory) yang dijelaskan oleh Saleh (2004) dalam Mahayani (2017) bahwa teori kepatuhan terdiri dari dua yaitu komitmen normatif melalui moralitas personal (normative commitment through morality) yang berarti mematuhi hukum karena hukum tersebut dianggap suatu keharusan dan komitmen normatif melalui legitimasi (normative commitment through legitimaty) berarti mematuhi peraturan karena otoritas penyusun hukum tersebut memiliki hak untuk mendikte perilaku.

Pemerintah Desa dalam mengelola keuangan desa harus berdasarkan dengan peraturan dan regulasi yang telah di tetapkan oleh Pemerintah yaitu UndangUndang Republik Indonesia Nomor 6 Tahun 2014 tentang Desa, Peraturan Menteri Dalam Negeri Republik Indonesia Nomor 113 Tahun 2014 tentang Pengelolaan Keuangan Desa dan Keputusan Walikota Denpasar Nomor 188.45/345/HK/2018 tentang Penetapan Besaran Alokasi Dana Desa kepada Desa di Kota Denpasar.

Kompetensi sumber daya manusia dalam pengelolaan keuangan desa didukung dengan pengetahuan, keahlihan dan perilaku. Sumber daya manusia yang kompeten memahami tugas pokok, memahami perencanaan dan penganggaran keuangan desa serta mampu menyusun laporan keuangan desa, mematuhi norma sosial dan aturan-aturan yang berlaku dan menolak segala bentuk suap.

Penjelasan tersebut di dukung oleh hasil penelitian di lapangan yang menunjukkan bahwa sebagaian besar Pemerintah Desa di 27 Desa Dinas yang 
berada Kota Denpasar memiliki pendidikan terakhir S1, yang berarti bahwa kompetensi sumber daya manusia dalam pengelolaan keuangan desa di desa yang berada di Kota Denpasar memiliki kompetensi yang baik. Sehingga dalam pengelolaan keuangan desa tindakan kecurangan dapat diminimalisir dan dihindarkan agar tujuan pemberian alokasi dana desa yang diperuntukan untuk kebutuhan masyarakat dapat sesuai.

Hasil penelitian ini selaras dengan penelitian-penelitian sebelumnya. Huslina (2015) menyatakan bahwa kompetensi aparatur berpengaruh positif terhadap efektivitas sistem pencegahan fraud. Penelitian ini didukung oleh penelitian yang dilakukan oleh Widiyarta et al., (2017) yang menyatakan bahwa kompetensi pemerintah desa berpengaruh positif dan signifikan terhadap pencegahan fraud dalam pengelolaan keuangan desa.

Hipotesis dua $\left(\mathrm{H}_{2}\right)$ menyatakan bahwa moralitas berpengaruh positif terhadap pencegahan fraud dalam pengelolaan keuangan desa. Berdasarkan hasil uji hipotesis yang dilakukan menunjukkan bahwa, moralitas berpengaruh positif terhadap pencegahan fraud dalam pengelolaan keuangan desa. Hasil penelitian ini didukung oleh teori perkembangan moral yang dijelaskan oleh Kohlberg dan Richard (1977) yaitu pada tahap pre-conventional dan post-conventional. Dimana pada tahap paling rendah (pre-conventional) dijelaskan bahwa individu mendasari tindakan yang dilakukannya karena takut terhadap hukum atau peraturan yang ada dan pada tahap tertinggi (post-conventional) individu mendasari tindakannya dengan memperhatikan kepentingan orang lain dan berdasarkan tindakannya pada hukum-hukum universal. 
Dengan konsep tersebut Pemerintah Desa dalam mengelola keuangan desa harus patuh dalam menjalankan tugas dan kewajibannya sesuai dengan amanah yang diberikan oleh Pemerintah melalui regulasi dan Undang-Undang yang telah ditetapkan agar pengelolaan keuangan desa dapat dipertanggungjawabkan, tidak hanya kepada Pemerintah Pusat dan Daerah tetapi juga masyarakat. Penggunaan alokasi dana desa oleh Pemerintah Desa harus sesuai dengan kebutuhan desa dan masyarakat, khusunya pada pembangunan desa, pembinaan dan pemberdayaan masyarakat. Moralitas yang baik sangat dibutuhkan karena moralitas yang baik mencerminkan perilaku yang baik. Oleh karena itu, dalam pengelolaan keuangan desa moralitas yang baik dari Pemerintah Desa sangat dibutuhkan agar penggunaan alokasi dana desa dapat digunakan sesuai dengan amanah yang di berikan oleh Pemerintah Pusat maupun Daerah dan juga untuk kepentingan orang banyak yaitu masyarakat desa. Moralitas yang dimiliki oleh Pemerintah Desa di Kota Denpasar dapat dicerminkan dari masa kerjanya yaitu dimana sebagian besar masa kerjanya yaitu 1 sampai 5 tahun dan diatas 5 tahun, hal tersebut menandakan bahwa di dalam penggunaan dan pengelolaan keuangan desa, Pemerintah Desa mementingkan kepentingan dan kebutuhan masyarakatnya dan bukan kepentingan pribadi. Maka dari itu moralitas sangat dibutuhkan untuk mencegah terjadinya tindakan kecurangan (fraud) dalam pengelolaan keuangan desa.

Hasil penelitian tersebut didukung oleh penelitian yang dilakukan oleh Wardana et al., (2017) yang menyatakan bahwa secara parsial moralitas aparat berpengaruh terhadap pencegahan fraud. Hal ini sejalan dengan penelitian yang 
dilakukan oleh Ramihah et al., (2018) yang membuktikan bahwa moralitas berpengaruh terhadap pencegahan fraud dalam alokasi dana desa.

Hipotesis tiga $\left(\mathrm{H}_{3}\right)$ menyatakan bahwa sistem pengendalian internal berpengaruh terhadap pencegahan fraud dalam pengelolaan keuangan desa. Hasil uji hipotesis yang dilakukan menunjukkan bahwa sistem pengendalian internal berpengaruh positif terhadap pencegahan fraud dalam pengelolaan keuangan desa. Hal tersebut didukung oleh konsep sistem pengendalian internal pada Peraturan Pemerintah Republik Indonesia Nomor 60 Tahun 2008 tentang Sistem Pengendalian Intern Pemerintah yang menjelaskan bahwa tujuan adanya sistem pengendalian internal adalah untuk memberikan keyakinan memadai atas tercapainya tujuan organisasi melalui kegiatan yang efektif dan efesien, keandalan laporan keuangan dan ketaatan terhadap peraturan perundang-undangan.

Dengan adanya sistem pengendalian internal yang kuat maka dapat mengurangi resiko atau kekeliruan maupun kesalahan-kesalahan dalam menyusun laporan keuangan desa sehingga dapat menciptakan laporan yang berkualitas yang sesuai dengan peraturan yang telah ditetapkan serta dapat di pertanggungjawabkan. Hasil penelitian tersebut menunjukkan bahwa sistem pengendalian internal pada Pemerintah Desa di 27 Desa Dinas yang berada di Kota Denpasar dalam pengelolaan keuangan desa adalah kuat. Dimana sistem pengendalian yang kuat didukung oleh lingkungan pengendalian, penilaian risiko, kegiatan pengendalian, informasi dan komunikasi serta pemantauan pengendalian internal. Sehingga tindakan kecurangan dalam pengelolaan keuangan desa dapat diminimalisir dan dicegah. 
Hasil penelitian ini selaras dengan penelitian-penelitian sebelumnya. Soleman (2013) menyatakan bahwa pengendalian internal berpengaruh positif terhadap pencegahan fraud. Penelitian tersebut sejalan dengan penelitian yang dilakukan oleh Atmadja dan Komang (2017) yang membuktikan bahwa sistem pengendalian internal berpengaruh terhadap pencegahan fraud dalam pengelolaan keuangan desa.

Hasil penelitian yang dilakukan mendukung agency theory yang menjelaskan bahwa di dalam pengelolaan keuangan desa, Pemerintah Desa (agent) mendapatkan amanah dari Pemerintah Pusat maupun Daerah (principal) untuk mengelola keuangan desa sesuai dengan kepentingan pembangunan desa, pembinaan dan pemberdayaan masyarakat desa. Penelitian ini dapat dijadikan acuan atau referensi untuk penelitian berikutnya yang sejenis.

Hasil penelitian ini dapat memberikan keyakinan kepada Pemerintah Pusat maupun Daerah dan masyarakat, bahwa penggunaan alokasi dana desa yang diberikan sudah sesuai dengan kepentingan dan kebutuhan masyarakat dan pembangunan desa. Sehingga, diharapkan pada tahun berikutnya pemberian alokasi dana desa kepada desa yang berada di Kota Denpasar dapat dinaikkan agar pembangunan desa, pembinaan dan pemberdayaan masyarakat lebih baik sehingga kesejahteraan masyarakat desa dapat ditingkatkan.

\section{SIMPULAN}

Kompetensi sumber daya manusia berpengaruh positif terhadap pencegahan fraud dalam pengelolaan keuangan desa. Hal ini berarti, kompetensi sumber daya 
manusia dalam pengetahuan, keahlihan dan berperilaku dapat mencegah fraud dalam pengelolaan keuangan desa. Sumber daya manusia yang kompeten memahami tugas pokok, memahami perencanaan dan penganggaran keuangan desa serta mampu menyusun laporan keuangan desa, mematuhi norma sosial dan aturan-aturan yang berlaku dan menolak segala bentuk suap.

Moralitas berpengaruh positif terhadap pencegahan fraud dalam pengelolaan keuangan desa. Moralitas yang baik dalam pengelolaan keuangan desa, didukung dengan kinerja bagus, tidak mementingkan kepentingan pribadi dan penggunaan keuangan desa mempertimbangkan prinsip kesejahteraan masyarakat dapat mencegah fraud (kecurangan).

Sistem pengendalian internal berpengaruh positif terhadap pencegahan fraud dalam pengelolaan keuangan desa. Semakin memadai sistem pengendalian internal dalam lingkungan pengendalian, penilaian risiko, kegiatan pengendalian, informasi dan komunikasi serta pemantauan pengendalian internal dapat mencegah kecurangan dalam pengelolaan keuangan desa.

Pemerintah Desa diharapkan dapat terus meningkatkan pemahaman dan pengetahuan tentang pengelolaan keuangan dengan mengikuti sosialisasi dan mengikuti bimbingan teknis sehingga pengelolaan keuangan desa sesuai dengan peraturan dan standar yang berlaku baik mulai tahap perencanaan hingga tahap pertanggungjawaban.

Pemerintah Desa diharapkan dapat terus meningkatkan kinerjanya agar penggunaan alokasi dana desa yang diberikan dapat bermanfaat untuk pembangunan desa dan masyarakat. 
Bagi peneliti selanjutnya diharapkan dapat menggunakan faktor-faktor lain yang dapat mempengaruhi pencegahan fraud dalam pengelolaan keuangan desa seperti whistleblowing system dan memperluas sampel penelitian tidak hanya di Kota Denpasar tetapi di Kabupaten lainnya di Bali untuk memperoleh perbandingan hasil.

\section{REFERENSI}

Adi, Moh. Risqi Kurnia, Komala Ardiyani, dan A. A. (2016). Analisis FaktorFaktor Penentu Kecurangan ( Fraud ) pada Sektor Pemerintahan (Studi Kasus pada Dinas Pendapatan Pengelolaan Keuangan dan Aset Daerah Kota Pekalongan). Jurnal Litbang Kota Pekalongan, 10, 1-10.

Agundu, P. U. C. (2014). Millennium Villages and Strategic Financial Management Vantage: Gate - Sachs Entrepreneurial Analytical Intersect. Journal of Economics and Sustainable Development, 5(28), 66-72.

Aini, Nurul, Made Aristia Prayudi, dan P. G. D. (2017). Pengaruh Perspektif Fraud Diamond Terhadap Kecenderungan Terjadinya Kecurangan (Fraud) Dalam Pengelolaan Keuangan Desa (Studi Empiris Pada Desa di Kabupaten Lombok Timur). E-Jurnal Akuntansi Universitas Pendidikan Ganesha, 8(2).

Amalya, Tuti, A. dan E. P. (2017). Determinants of Village Financial Management and Its Implication toward Accountability: Study on Village Governance in West Lombok Regency. International Journal of Research in Advent Technology, 5(12), 15-23.

Azlina, Nur, Amir Hasan, D. dan I. M. (2017). The Effectiveness of Village Fund Management (Case Study at Villages in Coastal Areas in Riau). International Journal of Economic Research, 14(12), 325-336. https://doi.org/10.1111/ele.12484

Dennyningrat, I. G. A. G. dan D. S. (2018). Pengaruh Sistem Pengendalian Intern Pemerintah dan Moralitas Individu Pada Kesalahan Akuntansi. E-Jurnal Akuntansi Universitas Udayana, 22, 1170-1196.

Dewi, Putu Feny Kharisma, G. A. Y. dan, \& Wahyuni, M. A. (2017). Pengaruh Moralitas, Integritas, Komitmen Organisasi, dan Pengendalian Internal Kas Terhadap Pencegahan Kecurangan (Fraud) dalam Pelaksanaan Program Subsidi Beras Bagi Masyarakat Berpendapatan Rendah (Studi Pada Desa di 
Kabupaten Buleleng). E-Journal S1 Ak Universitas Pendidikan Ganesha, $8(2)$.

Eisenhardt, K. M. (1989). Building Theories from Case Study Research. The Academy of Management Review. https://doi.org/10.2307/258557

Husin, D. (2016). Flexibility of Budget Accountability Using Flow Modification in the Design of Village Financial Accounting. Asia Pasific Fraud Journal, 1(1), 19-35. https://doi.org/10.21532/apfj.001.16.01.01.02

Indayani, Fitri, L. dan R. R. G. (2018). The Effect Of Village Characteristics Toward Village Finance Efficiency In Lampung, Indonesia. International Journal of Scientific \& Technology Research, 7(4), 93-99.

Jensen, M. C., Meckling, W. H., Jensen, C., \& Meckling, H. (1976). Theory of the Firm: Managerial Behavior, Agency Costs and Ownership Structure. Journal of Financial Economics. https://doi.org/10.1016/0304405X(76)90026-X

Joseph, O. N. O. A. dan J. B. (2015). Effect of Internal Control on Fraud Detection and Prevention in District Treasuries of Kakamega County. International Journal of Business and Management Invention, 4(1), 47-57.

Junia, N. (2016). Pengaruh Moralitas Aparat, Kesesuaian Kompensasi, dan Ketaatan Aturan Akuntansi Terhadap Kecenderungan Kecurangan Akuntansi (Studi Empiris pada Satuan Kerja Perangkat Daerah Kabupaten Kampar). JOM Fekon, 3(1), 1623-1637.

Kazimoto, P. (2013). Analysis Of Village Financial Management Challenges in Arumeru District in Tanzania. International Journal of Research In Social Sciences, 3(2), 72-77.

Kohlberg, L. dan R. H. (1977). Moral development: A Review of The Theory. Theory Into Practice, 16(2), 53-59. https://doi.org/10.1080/00405847709542675

Kurniasari, Novia Tri, A. F. dan N. R. (2018). Strategi Pencegahan Kecurangan (Fraud) dalam Pengelolaan Keuangan Pemerintah Menggunakan Analytical Hierarchy Process. Jurnal Manajemen Pembangunan, 10, 24-32.

Lane, J. E. (2013). The Principal-Agent Approach to Politics: Policy Implementation and Public Policy-Making. Open Journal of Political Science, 3(2), 85-89. https://doi.org/10.4236/ojps.2013.32012

Liyanarachchi, G. dan, \& Newdick, C. (2009). The Impact of Moral Reasoning and Retaliation on Whistle-Blowing New Zealand Evidence. Journal of 
Business Ethics, 8(9). https://doi.org/10.1007/s10551-008-9983-X

Manossoh, H. (2016). Faktor-Faktor Penyebab Terjadinya Fraud Pada Pemerintah Di Provinsi Sulawesi Utara. Emba.

Novikasari, Y. (2017). Pengaruh Moralitas Individu, Sistem Pengendalian Intern Pemerintah dan Ketaatan Aturan Akuntansi Terhadap Kecenderungan Kecurangan Akuntansi (Studi Empiris pada SKPD Kabupaten Kuantan Singingi). JOM Fekon, 4(1), 1516-1530.

Oliviera, C. B. de dan J. R. F. F. (2017). Agency Problems In The Public Sector: The Role Of Mediators Between Central Administration Of City Hall And Executive Bodies. Brazilian Journal Of Public Administration, 51(4), 596615.

Prawira, I Made Darma, N. T. H. dan N. A. S. (2014). Pengaruh Moralitas Individu, Asimetri Informasi dan Efektivitas Pengendalian Internal Terhadap Kecenderungan Kecurangan (Fraud) Akuntansi (Studi Empiris pada Badan Usaha Milik Daerah Kabupaten Buleleng). E-Journal S1 Ak Universitas Pendidikan Ganesha, 2(1).

Rahimah, Laila Nur, Yetty Murni, S. L. (2018). Pengaruh Penyajian Laporan Keuangan Desa, Lingkungan Pengendalian dan Moralitas Individu Terhadap Pencegahan Fraud yang Terjadi dalam Pengelolaan Alokasi Dana Desa. Jurnal Ilmiah Ilmu Ekonomi, 6(12), 139-154.

Setiawan, S. (2018). The Effect of Internal Control and Individual Morality on The Tendency of Accounting Fraud. Asia Pacific Fraud Journal, 3(1), 3341. https://doi.org/10.21532/apfj.001.18.03.01.04

Syaifullah, M. (2017). Understanding of Village Apparatus on Implementation Accounting Villages. International Journal of Science and Research, 6(8), 1168-1175. https://doi.org/10.21275/ART20176211

Temenggung, Y. A. (2016). Rural Financial Management in Perspective Law No . 6 of 2014 Concerning the Village. International Journal Of Social Sciences, $43(1), 42-54$.

Usman, B. A. U. T. T. dan M. R. (2015). Pengaruh Tata Kelola Pemerintahan Dan Pengendalian Internal Terhadap Pencegahan Kecurangan (Studi Pada SKPD Pemerintah Kabupaten Indragiri Hilir). Jurnal Ekonomi, 23, 18-34.

Wardana, I Gede Adi Kusuma, E. S. dan M. A. W. (2017). Pengaruh Pengendalian Internal, Whistleblowing System Dan Moralitas Aparat Terhadap Pencegahan Fraud Pada Dinas Pekerjaan Umum Kabupaten Buleleng. E-Journal S1 Ak Universitas Pendidikan Ganesha, 8. 
Putu Santi Putri Laksmi dan I Ketut Sujana. Pengaruh ...

Widarnawati, Baiq Wiwik, B. S. dan L. S. (2018). Factors Affecting of Village Financial Management snd Its Implications for Stakeholders Trust (Study on Villages in Central Lombok, Indonesia). International Journal of Economics, Commerce and Management, 6(3), 534-548. 